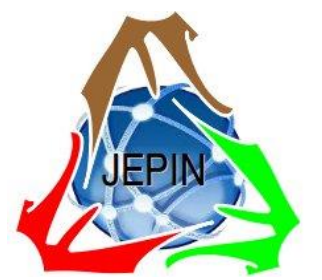

\title{
Integrasi Microlecture pada Kelas Virtual Berbasis $3 D$ Virtual Learning Environment
}

\author{
Adhi Rizal ${ }^{\# 1}$, Dadang Yusup*2 \\ \#*Program Studi Teknik Informatika, Universitas Singaperbangsa Karawang \\ Jl. H.S. Ronggowaluyo, Teluk Jambe, Karawang \\ ladhi.rizalestaff.unsika.ac.id \\ 2dadang.dyfestaff.ac.id
}

\begin{abstract}
Abstrak- Penelitian ini bertujuan untuk mengintegrasikan dan mengimplementasikan konsep microlecture ke dalam lingkungan virtual 3 dimensi. Micro-video yang dikembangkan terdiri dari tiga bagian utama, yaitu bagian pendahuluan, inti, dan penutup dengan durasi masingmasing sekitar 30 detik, 12 menit, dan 11 detik. Micro-video dibuat dengan menggunakan bantuan kamera, microphone, dan beberapa video editor tools. Sedangkan lingkungan pembelajaran virtual (Virtual Learning Environment-VLE) dikembangkan berdasarkan framework ADDIE (Analysis, Design, Development, Implementation, Evaluation). Setelah lingkungan virtual berhasil dikembangkan, maka micro-video diintegrasikan ke dalamnya dan disajikan melalui objek presenter sehingga dapat dipelajari oleh peserta didik. Hasil implementasi menunjukan bahwa integrasi konsep yang diusulkan dapat meningkatkan hasil belajar peserta didik dibandingkan dengan konsep konvensional. Selain itu, hasil penerimaan pengguna berdasdarkan HMSAM (Hedonic Motivation System Adoption Model) menunjukan bahwa sistem yang dikembangkan dapat diterima untuk digunakan dalam proses pembelajaran.
\end{abstract}

Kata kunci - microlecture, VLE, ADDIE, hasil belajar, HMSAM

\section{Pendahuluan}

Pemanfaatan teknologi dalam bidang pendidikan dapat mempengaruhi lingkungan dan proses pembelajaran menjadi lebih dinamis, interaktif, dan dapat meningkatkan motivasi belajar. Peserta didik dan pengajar dapat melaksanakan proses pembelajaran di mana dan kapan saja. Salah satu penyebab hal ini adalah penerapan konten multimedia di lingkungan belajar yang disampaikan dengan bantuan media elektronik serta teknologi informasi dan komunikasi yang pada umumnya disebut dengan $e$ learning .

Dari berbagai jenis e-learning yang dapat diterapkan, lingkungan pembelajaran digital 3 dimensi yang juga merupakan Course Management System (CMS) merupakan salah satu konsep e-learning yang banyak digunakan selama beberapa tahun terakhir [1], [2]. VLE merupakan platform pembelajaran yang dikembangkan menggunakan komputer yang memiliki beberapa karakteristik yaitu dinamis, virtualisasi dunia nyata (seperti di dalam game), dan biasanya direpresentasikan kepada pengguna menggunakan grafis 3 dimensi [3], sehingga dapat disebut juga sebagai 3D Virtual World (3D VW).

3D VW memiliki potensi yang sangat besar untuk diterapkan sebagai platform pembelajaran inovatif di masa depan. Selain itu platform ini juga menyediakan beberapa fitur khusus dan unik dengan melibatkan peserta didik kedalam pembelajaran kontekstual yang mirip dengan dunia nyata [4].

Terdapat beberapa penelitian yang menunjukan bahwa 3D VW dapat diterapkan secara efektif pada aktivitas pembelajaran di sejumlah institusi pendidikan [5], [1], [6], [7]. Namun dari semua keunggulan yang ditawarkan, 3D VW juga memiliki beberapa kekurangan. Ketika peserta didik menggunakan sistem ini pertama kali, biasanya mereka tidak mengetahui apa yang harus dilakukan [8]. Selain itu peserta didik juga dapat kehilangan fokusnya terhadap proses pembelajaran yang disebabkan oleh beberapa hal, misalnya peserta didik lebih tertarik untuk menjelajahi lingkungan virtual [9], termasuk melakukan penyesuaian terhadap avatarnya dan permasalahan teknis lain di dalam 3D VW [10]. Selain itu, dengan penelitian yang dilakukan oleh [11] menyatakan bahwa tingkat konsentrasi peserta didik dalam belajar hanya berlangsung sekitar 10 menit di dalam kelas.

Selain dengan memanfaatakan teknologi, untuk menciptakan suatu proses pembelajaran yang lebih efektif, menarik, dan meningkatkan motivasi peserta didik dibutuhkan suatu upaya lain yang harus dilakukan. Oleh karena itu, untuk mengimbangi minimnya daya tahan konsentrasi yang dialami peserta didik, maka dibutuhkan suatu kegaitan pembelajaran yang relatif singkat namun memiliki fokus terhadap isu atau topik permasalahan tertentu dengan indikator pembelajaran yang jelas [12], [11].

Salah satu cara yang dapat dilakukan adalah dengan menerapkan konsep Microlecture [11], [13]. Microlecture merupakan suatu konsep pembelajaran yang memanfaatkan video berdurasi singkat [14] sekitar 3 sampai 10 menit, namun tidak lebih dari 15 menit [15] dan 
dikombinasikan dengan tugas atau diskusi agar tercipta kelas yang lebih interaktif.

Berdasarkan permasalahan yang telah dipaparkan, maka penelitian ini bertujuan untuk mengintegrasikan konsep microlecture ke dalam kegiatan pembelajaran menggunakan 3D-VLE sebagai lingkungan pembelajaran. Hal ini dilakukan karena secara terpisah keduanya merupakan sarana yang sangat baik untuk meningkatkan kualitas proses belajar mengajar [1], [16]. Selain itu, untuk mengetahui sejauh mana keberhasilan usulan integrasi yang dilakukan, maka dua tahap pengujian akan dilakukan. Pengujian pertama dilakukan untuk menginvestigasi pengaruh usulan konsep integrasi terhadap hasil belajar peserta didik. Kemudian pengujian selanjutnya dilakukan untuk mengidentifikasi respon peserta didik terhadap sistem menggunakan model penilaian HMSAM [17]. Dengan adanya integrasi ini diharapkan kualitas pembelajaran dapat meningkat dan diperoleh pemahaman baru mengenai alternatif konsep pembelajaran yang dapat dilaksanakan oleh peserta didik dan pengajar.

\section{Penelitian Terkait}

Beberapa penelitian mengenai Microlecture telah dilakukan sebelumnya. Penelitian yang dilakukan oleh [18] bertujuan untuk mengenalkan konsep micro-class dan proses proses pelaksanaannya. Penelitian ini melakukan analisis terhadap delapan klasifikasi Microlecture dan kemudian menerapkannya untuk diterapkan pada topik pembelajaran Instalasi dan Perbaikan Sistem Operasi Komputer. Hasil dari penelitian ini adalah tahapan secara rinci berupa script untuk membuat microlecture video. Walaupun demikian penelitian ini tidak menerapkan microlecture video yang dikembangkan.

Selain itu [19] mengembangkan microlecture platform yang diterapkan pada kegiatan pembelajaran dengan tema General City Planning. Platform ini mencakup beberapa fungsi, beberapa diantaranya adalah perangkat microlecture, perangkat untuk merekam video real-time dan video broadcast di dalam kelas, serta perangkat untuk menyajikan pertanyaan dan jawaban. Hasil penelitian ini menunjukan bahwa microlecture platform yang dikembangkan dapat digunakan dengan mudah sehingga optimal untuk diterapkan pada kegiatan pembelajaran antara peserta didik dan pengajar.

Berikutnya [20] berupaya menginvestigasi penerapan microlecture pada topik pembelajaran English for Business menggunakan pendekatan studi kasus. Penelitian ini fokus pada empat bidang, yaitu penyajian konten pembelajaran dengan teknologi, layanan pendukung pembelajaran, manajemen pembelajaran, dan pengalaman belajar peserta didik. Temuan dari penelitian menunjukan bahwa sebagian besar peserta didik puas dengan pembelajaran berbasis microlecture termasuk penerapan model flipped classroom yang diterapkan di dalamnya untuk mengoptimalkan proses pembelajaran.

Penelitian yang dilakukan oleh [15] juga mengembangkan microlecture yang diterapkan pada perangkat smartphone sehingga dapat memicu motivasi peserta didik dan meningkatkan kesadaran untuk melakukan inovasi. Tidak jauh berbeda, referensi [11] juga mengembangkan microlecture dengan pembelajaran berbasis mobile yang kemudian disebut dengan Micrelecture Mobile Learning System (MMLS). Hasil penelitian ini menunjukan bahwa konsep yang diusulkan dapat meningkatkan hasil belajar peserta didik dibandingkan dengan metode konvensional.

Beberapa penelitian tersebut berupaya mengembangkan proses kegiatan belajar mengajar dengan menerapkan konsep microlecture dan didukung oleh berbagai teknologi penunjang. Berbeda dengan penelitian-penelitian yang telah dilakukan, penelitian ini mengusulkan integrasi konsep microlecture dengan lingkungan belajar virtual yang dilengkapi dengan objek dan lingkungan 3 dimensi.

\section{METODOLOGI PENELITIAN}

Secara garis besar, penelitian ini dilaksanakan dengan mengadaptasi model atau framework ADDIE [21] yang terdiri dari lima tahap sesuai akronimnya, yaitu tahap analisis, tahap perencanaan, tahap pengembangan, tahap implementasi, dan tahap evaluasi. Secara lebih rinci, tahapan yang akan dilakukan dapat dilihat pada TABEL I1.

Kemudian untuk pengembangan konten microlecture video, penelitian ini mengadaptasi [22], [13] dengan tahapan yang ditunjukan pada Gambar. 1.

TABEL I

TAHAPAN PENELITIAN BERDASARKAN ADDIE MODEL

\begin{tabular}{|c|c|c|}
\hline Tahap & Aktivitas & Hasil \\
\hline Analisis & $\begin{array}{l}\text { - Mengidentifikasi } \\
\text { pengguna sistem } \\
\text { - Analisis konsep } \\
\text { microlecture }\end{array}$ & $\begin{array}{l}\text { - Karakteristik } \\
\text { pengguna } \\
\text { - Karakteristik } \\
\text { microlecture }\end{array}$ \\
\hline Perancangan & $\begin{array}{l}\text { - Merancang kegiatan } \\
\text { pembelajaran } \\
\text { - Merancang bahan ajar } \\
\text { (microlecture video) } \\
\text { - Merancang sistem } \\
\text { - Merancang metode } \\
\text { evaluasi }\end{array}$ & $\begin{array}{l}\text { - Skenario } \\
\text { pembelajaran } \\
\text { - Rancangan bahan } \\
\text { - ajar } \\
\text { - Arsitektur sistem } \\
\text { - Skenario evaluasi }\end{array}$ \\
\hline Pengembangan & $\begin{array}{l}\text { - Mengembangkan objek } \\
\text { pembelajaran dalam } \\
\text { sistem } \\
\text { - Mengembangkan } \\
\text { microlecture video }\end{array}$ & $\begin{array}{l}\text { - Objek 3D } \\
\text { - Konten } \\
\text { pembelajaran } \\
\text { (microlecture } \\
\text { video) }\end{array}$ \\
\hline Implementasi & $\begin{array}{l}\text { - Instalasi sistem } \\
\text { - Distribusi sistem } \\
\text { - Pengelolaan kegiatan } \\
\text { pembelajaran }\end{array}$ & $\begin{array}{l}\text { Pelaksanaan kegiatan } \\
\text { pembelajaran }\end{array}$ \\
\hline Evaluasi & $\begin{array}{l}\text { - Evaluasi hasil belajar } \\
\text { - Pengujian respon } \\
\text { peserta didik }\end{array}$ & $\begin{array}{l}\text { - Hasil belajar } \\
\text { peserta didik } \\
\text { - Tingkat } \\
\text { penerimaan peserta } \\
\text { didik }\end{array}$ \\
\hline
\end{tabular}




\section{HASIL DAN PEMBAHASAN}

\section{A. Analisis}

Di tahap pertama ini karakteristik pengguna dan karakteristik dari microlecture berhasil teridentifikasi. Pengguna dari sistem ini terdiri dari tiga jenis pengguna utama, yaitu peserta didik pengajar, dan administrator. Setiap kategori pengguna beserta aktivitas yang dapat dilakukannya di dalam sistem secara rinci ditunjukan pada TABEL II2.

TABEL II

AKTIVITAS PENGGUNA DI DALAM SISTEM

\begin{tabular}{|c|c|}
\hline Pengguna & Aktivitas \\
\hline Peserta didik & $\begin{array}{l}\text { Menggunakan chat untuk berdiskusi dengan } \\
\text { pengajar atau peserta didik lain } \\
\text { - Mengakses konten pembelajaran } \\
\text { - Mengikuti kuis } \\
\text { - Melihat nilai hasil belajar }\end{array}$ \\
\hline Pengajar & $\begin{array}{l}\text { Membuat bahan ajar } \\
\text { - Meng-unggah bahan ajar } \\
\text { - Membuat soal (kuis) } \\
\text { - Memaftarkan peserta didik } \\
\text { Mengakses chat untuk berkomunikasi dengan } \\
\text { peserta didik }\end{array}$ \\
\hline Administrator & $\begin{array}{l}\text { - Mengelola objek dan lingkungan virtual } \\
\text { - Mendaftarkan peserta didik } \\
\text { - Meng-unggah bahan ajar } \\
\text { - Membuat kuis } \\
\text { - Memantarkan peserta didik } \\
\text { Memtivitas peserta didik }\end{array}$ \\
\hline
\end{tabular}

Secara umum pengajar dan administrator memiliki hak yang sama, namun terdapat administrator memiliki kelebihan untuk mengelola objek dan lingkungan virtual termasuk membuat, mengubah, atau menghapusnya. Sedangkan untuk peserta didik dibatasi hak aksesnya hanya untuk menggunakan objek-objek pembelajaran yang ada di dunia virtual.

Paparkan konsep inti yang akan dikaji selama proses pembelajaran

Paparkan pendahuluan (pengenalan) dan kesimpulan mengenai konsep utama pembelajaran selama 15-30 detik pertama. Tahap ini akan memberikan konteks pada konsep inti pembelajaran

Buat rekaman video yang terdiri dari gabungan pendahuluan, konsep inti, dan kesimpulan pembelajaran menggunakan kamera dan microphone

Kembangkan tugas untuk mengarahkan peserta didik melakukan eksplorasi terhadap konsep inti pembelajaran

Gambar. 1 Tahap pengembangan microlecture video

Pengembangan microlecture dalam penelitian ini dilakukan dengan mengadaptasi struktur model microlecture [23] yang ditunjukan pada Gambar. 2. Terdapat beberapa karakteristik yang harus diperhatikan dalam membuat microlecture yaitu identifikasi pengaruh pembelajaran, norma pengajaran, perancangan struktur pengetahuan, serta pemilihan topik dan konten pembelajaran [23]. Berdasarkan hal ini, maka microlecture yang dikembangkan memiliki beberapa kelebihan, yaitu merupakan model pembelajaran singkat, pembuatan materi pembelajaran lebih cepat, fokus pada inti pembelajaran, dapat dipelajari berulang, dan efisiensi waktu.

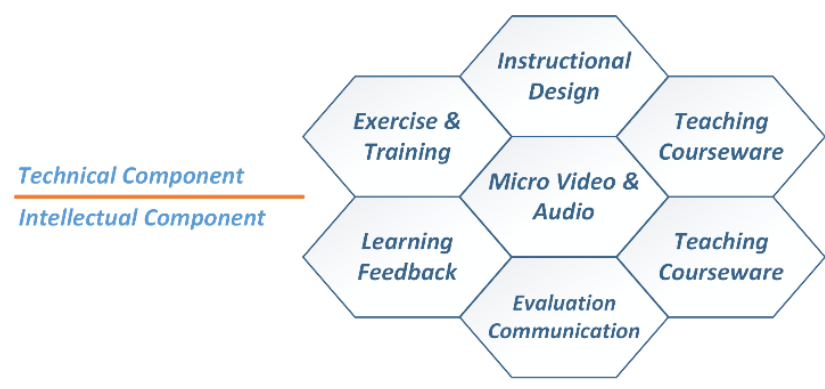

Gambar. 2 Model microlecture

\section{B. Perancangan}

Pada tahap ini dihasilkan prosedur kegiatan pembelajaran, rancangan bahan ajar yang akan disampaikan dengan konsep microlecture, arsitektur sistem dan skenario evaluasi pembelajaran.

1) Skenario Pembelajaran: Kegiatan pembelajaran dilaksanakan berdasarkan metode kuasi eksperimen yang bertujuan untuk mengetahui pengaruh penerapan integrasi microlecture dengan 3D-VLE terhadap hasil belajar peserta didik. Berdasarkan hal ini, maka Langkah pertama peserta didik dibagi menjadi dua kelompok kelas, yaitu kelas kontrol dan kelas eksperimen.

Di awal kegiatan pembelajaran, setiap kelas diberikan pre-test. Sedangkan di akhir kegiatan pembelajaran, setiap kelas diberikan post-test. Namun kedua kelas tersebut menerima perlakukan berbeda ketika pelaksanaan kegiatan inti pembelajaran. Materi pembelajaran di kelas kontrol disampaikan secara konvensional (tidak ada perlakukan khusus). Sedangkan penyampaian materi pembelajaran dan pelaksanaan post-test dilakukan dengan menggunakan konsep micro-video yang disampaikan melalui teknologi 3D-VLE.

Pada kelas eksperimen, setiap pengguna harus mengikuti alur yang ditunjukan pada Gambar. 3. Berdasarkan hal ini, maka alur pembelajaran di dalam sistem dibagi menjadi 3 kelompok aktivitas berdasarkan penggunanya yaitu kegiatan pembelajaran yang dilakukan oleh peserta didik dan pengajar serta alur pengelolaan sistem dan akun pengguna oleh administrator.

2) Perancangan bahan ajar: Microlecture dikembangkan berdasarkan salah satu sub topik di mata kuliah komputer dan masyarakat, yaitu siklus tren perkembangan teknologi berdasarkan Gartner Hype Cycle. Micro-video yang akan diimplementasikan dirancang berdasarkan Gambar. 1. Oleh karena itu, micro-video ini terdiri dari tiga tahap penyampaian materi, yaitu bagian pembukaan, inti, dan penutup dengan durasinya masing- 
masing. Tahap pembuatan micro-video secara lebih rinci dipaparkan pada tahap pengembangan.

3) Arsitektur Sistem: Secara garis besar, sistem 3DVLE dibangun berdasarkan arsitektur client-server. Server terdiri dari sebuah komputer yang terdiri dari beberapa teknologi, yaitu OpenSimulator [24] server, SLOODLE (Simulation Linked Object Oriented Dynamic Learning Environment), dan Moodle (Modular Object-Oriented Dynamic Learning Environment).

OpenSimulator merupakan aplikasi server untuk menyediakan lingkungan 3 dimensi berbasis open-source dengan fitur multi-platform dan multi-user. OpenSimulator berfungsi untuk mengembangkan dan menyediakan lingkungan virtual yang ada di dalam sistem. Selain itu, aplikasi ini juga merupakan penghubung sehingga klien dapat berkomunikasi (bertukar data) dengan server.

Selain itu, untuk mendukung proses pembelajaran sehingga semua data atau informasi pengajar, materi (konten) pembelajaran, dan peserta didik dapat disimpan dan dikelola dengan baik, maka sistem ini juga menerapkan Moodle sebagai Learning Management System (LMS). Moodle merupakan platform e-learning yang memungkinkan pengajar mengembangkan kegiatan pembelajaran yang dapat diakses secara online dan mendukung interaksi dengan peserta didik. Beberapa data yang dikelola oleh Moodle di dalam sistem ini adalah detail akun pengguna, konten/materi pembelajaran beserta soalsoal latihan atau kuis dan tugas, perkembangan belajar peserta didik yang dilihat dari kehadiran, interaksi, nilai dan data lainnya.

Kemudian komponen inti di dalam server selanjutnya adalah SLOODLE [25]. SLOODLE berfungsi sebagai jembatan yang mengintegrasikan lingkungan pembelajaran berbasis OpenSimulator dengan Moodle. Dengan kata lain OpenSimulator dapat digunakan sebagai klien 3D alternatif untuk Moodle dan menggantikan halaman page yang sebagian besar berbasis teks [26].

4) Skenario Evaluasi: Di dalam penelitian ini, proses evaluasi dibedakan menjadi dua, yaitu investigasi pengaruh penerapan integrasi konsep terhadap hasil belajar peserta didik dan identifikasi tingkat penerimaan atau respon pengguna. Sesuai dengan perencanaan prosedur kegiatan pembelajaran, maka proses identifikasi pengaruh penerapan usulan konsep terhadap hasil belajar peserta didik dilakukan berdasarkan hasil pre-test dan post-test. Kedua nilai pre-test dan post-test dari kelas kontrol dan eksperimen dibandingkan untuk melihat apakah terdapat perbedaan (Gain). Setelah dilakukan kalkulasi Gain, tahap berikutnya adalah melakukan pengujian untuk menginvestigasi apakah terdapat dampak (baik signifikan atau tidak) penerapan usulan konsep terhadap hasil belajar. Oleh karena itu penelitian ini menggunakan uji-t 2 sampel independen dengan dua kriteria hipotesis, yaitu $\mathrm{H}_{0}$ : tidak terdapat perbedaan peningkatan hasil belajar antara kelas kontrol dengan kelas eksperimen dam $\mathrm{H}_{1}$ : terdapat perbedaan peningkatan hasil belajar antara kelas kontrol dengan kelas eksperimen. Berdasarkan hasil kalkulasi uji-t, jika nilai signifikansi lebih besar dari 0,05 maka $\mathrm{H}_{0}$ diterima dan $\mathrm{H}_{1}$ ditolak, dan sebaliknya.

Untuk mengidentifikasi pengguna, penelitian ini mengembangkan instrumen kuesioner yang dikembangkan berdasarkan variabel-variabel yang ada pada HMSAM. HMSAM merupakan suatu model yang terdiri dari 7 variabel dan digunakan untuk mengidentifikasi tingkat penggunaan dan adopsi (penerimaan) dari suatu sistem [17] Variabel yang terdapat pada HMSAM di tunjukan pada Gambar. 5.

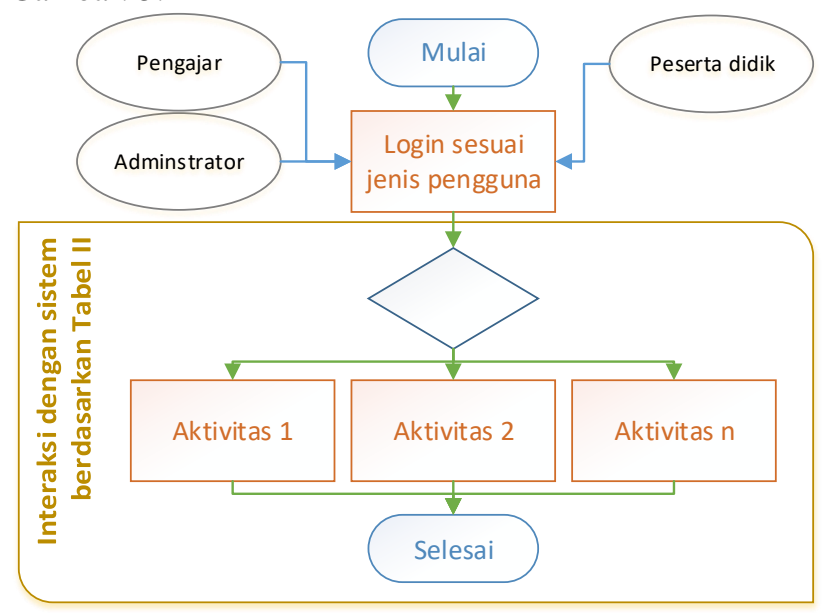

Gambar. 3 Diagram aktivitas pengguna

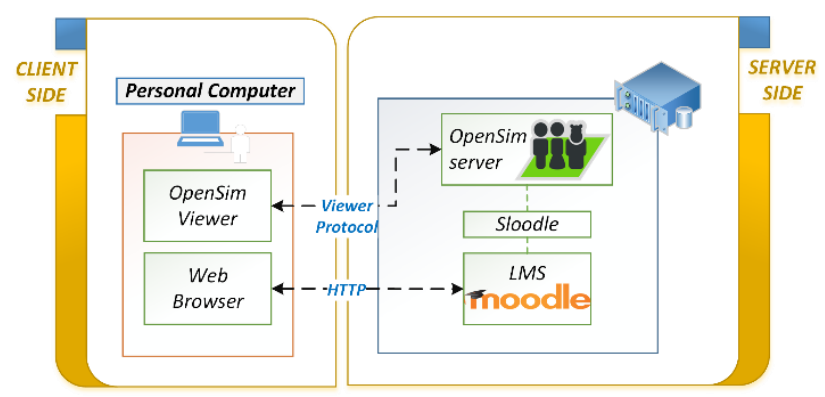

Gambar. 4 Arsitektur 3D-VLE system

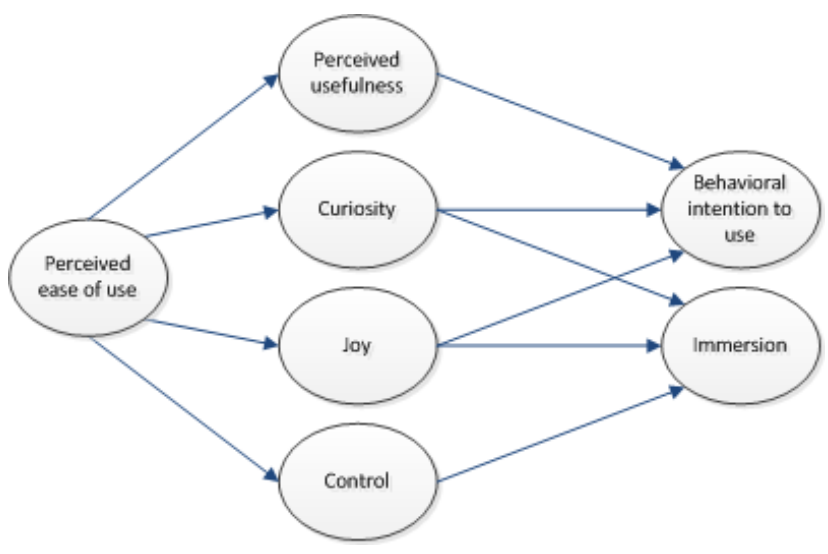

Gambar. 5 Variabel HMSAM [17] 


\section{Pengembangan}

Setelah dilakukan perancangan, maka tahap ini dilaksanakan untuk merealisasikan semua komponen pembelajaran yang telah disiapkan. Hasil dari tahap pengembangan ini adalah objek dan lingkungan 3D-VLE, konten pembelajaran berupa microlecture video, dan sistem 3D-VLE secara keseluruhan.

1) Objek dan Lingkungan 3D: Di dalam 3D-VLE, pengguna (pengajar, peserta didik, maupun administrator) dan objek pembelajaran lainnya masing-masing direpresentasikan sebagai avatar dan grafik digital 3 dimensi seperti yang ada pada dunia nyata. Berdasarkan hal ini maka setiap kategori pengguna dapat berinteraksi dengan objek pembelajaran yang ada di dalam sistem sesuai hak aksesnya, seperti yang ditunjukan pada TABEL III3.

TABEL III

FUNGSI OBJEK 3D DALAM AKTIVITAS PEMBELAJARAN

\begin{tabular}{|l|l|}
\hline \multicolumn{1}{|c|}{ Objek 3D VLE } & \multicolumn{1}{c|}{ Fungsi / Aktivitas } \\
\hline Reg-enroll booth & Administrasi \\
\hline $\begin{array}{l}\text { Presenter (Video/Slide) atau } \\
\text { objek 3D lain }\end{array}$ & Konten Pembelajaran \\
\hline $\begin{array}{l}\text { - Quiz chair } \\
\text { - Papan skor }\end{array}$ & Penilaian \\
\hline - Chat & Interaksi \\
\hline
\end{tabular}

Beberapa tampilan objek dan lingkungan pembelajaran pada sistem ditunjukan pada Gambar. 6, Gambar. 7, Gambar. 8, dan Gambar. 9. Gambar. 6 menunjukan pengguna yang direpresentasikan sebagai avatar. Setiap pengguna dapat melakukan penyesuaian (kustomisasi) terhadap avatarnya masing-masing, misalnya mengubah pakaian yang dikenakan atau mengubah postur wajah dan tubuh.

Kemudian Gambar. 7 menunjukan objek Reg-enroll booth. Objek ini dikhususkan untuk peserta didik yang berfungsi agar peserta didik yang bersangkutan dapat mengikuti ujian/kuis sehingga semua informasi akunnya (termasuk nilai) terekam di dalam sistem. Ketika peserta didik mengakses (meng-klik) objek ini, maka akan muncul pop-up window yang akan mengarahkan ke halaman login Moodle melalui browser untuk memasukan akunnya masing-masing. Setelah itu meraka harus mendaftarkan diri (enroll) ke mata pelajaran (course) yang akan diikuti. Setelah berhasil mendaftarkan diri, maka akun peserta didik di dalam OpenSimulator akan terintegrasi atau terhubung secara otomatis dengan Moodle.

Setelah mengakses Reg-enroll booth, maka peserta didik dapat mengikuti pembelajaran di dalam kelas yang ditunjukan pada Gambar. 8. Ruang kelas terdiri dari beberapa objek penting, diantaranya adalah kursi, meja, dan presenter. Presenter merupakan objek yang digunakan untuk menampilkan konten pembelajaran dengan berbagai media, misalnya dalam bentuk gambar (slide), menampilkan audio/video secara langsung, maupun sebagai browser (menampilkan halaman web). Di dalam sistem yang dikembangkan, presenter digunakan untuk menampilkan slide bahan ajar dan micro-video pembelajaran. Sebelum video pembelajaran ditampilkan melalui presenter, video ini diunggah terlebih dahulu ke youtube. Oleh karena itu, presenter yang digunakan berfungsi sebagai browser untuk mengakses video pembelajaran melalui halaman web youtube.

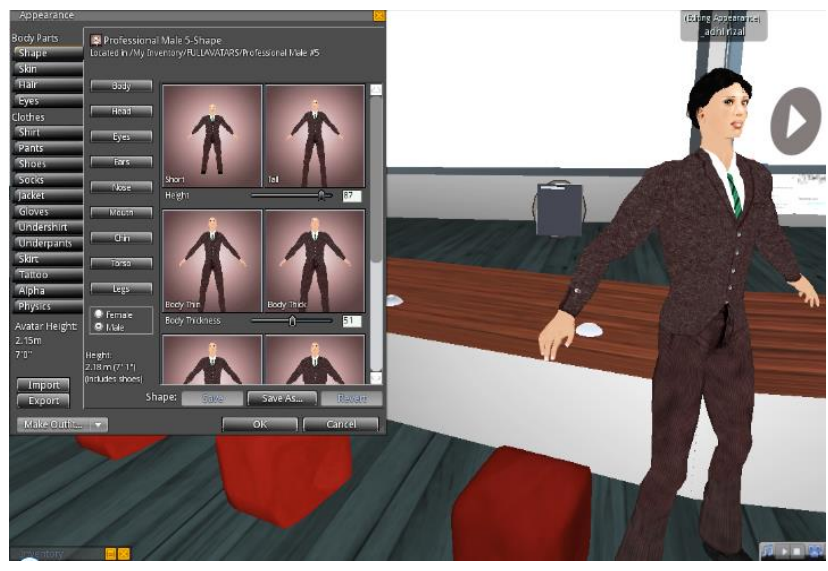

Gambar. 6 Kustomisasi avatar pengguna

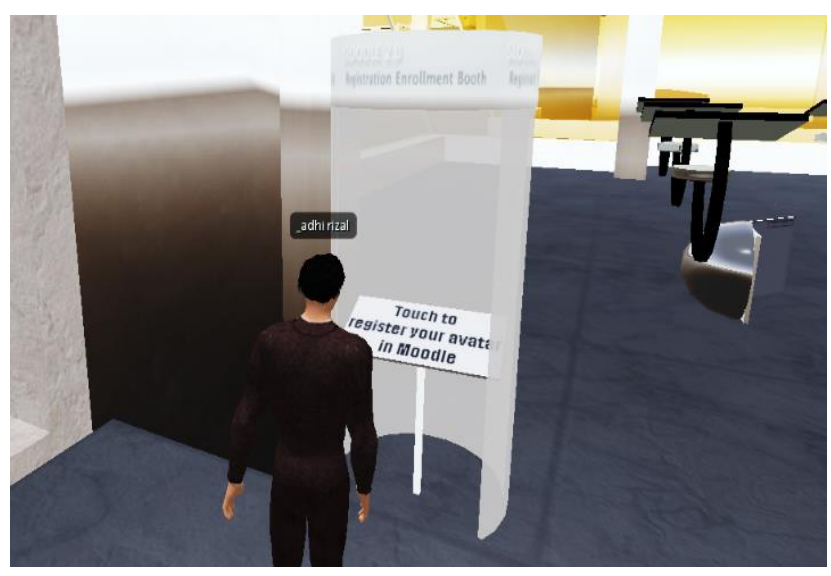

Gambar. 7 Reg-enroll booth

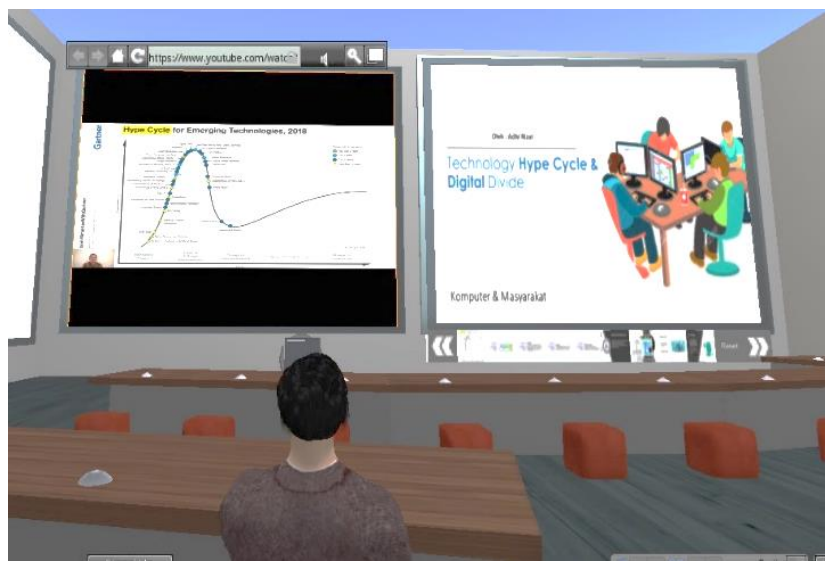

Gambar. 8 Ruang kelas 


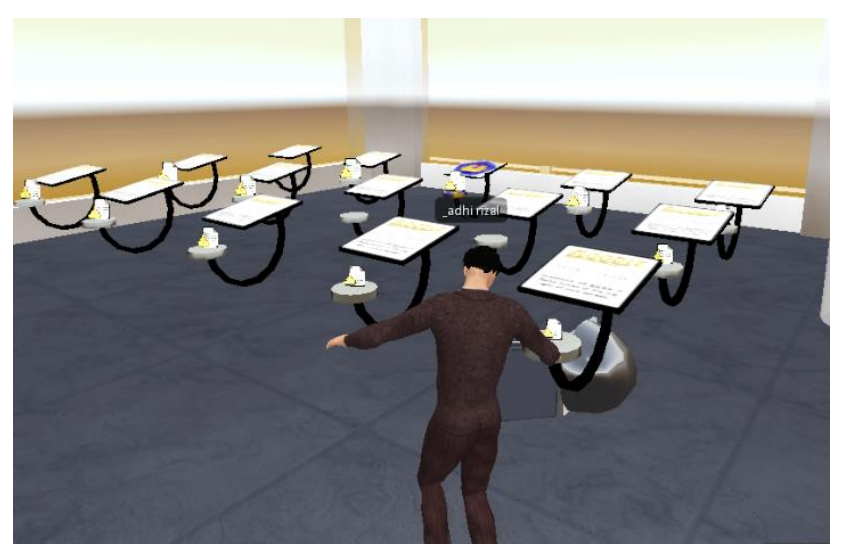

Gambar. 9 Quiz chair (ruang ujian)

Lingkungan belajar yang dikembangkan berikutnya adalah ruang ujian yang terpisah dari ruang kelas. Di dalam ruangan ini terdapat sebuah objek utama, yaitu quiz chair yang dapat oleh peserta didik untuk duduk dan mengerjakan soal. Jika peserta didik tidak mendaftarkan dirinya terlebih dahulu malalui reg-enroll booth, maka mereka tidak dapat mengakses quiz chair. Ketika peserta didik berhasil mengakses (duduk) quiz chair, maka setiap pertanyaan akan muncul melalui jendela pop-up di sudut atas kanan layar. Kemudian peserta harus memilih jawaban yang paling tepat diantara pilihan jawaban yang ada. Ketika setiap soal yang dijawab benar, maka quiz chair akan bergerak semakin ke atas (bertambah ketinggian). Sedangkan jika mahasiswa menjawab salah, maka quiz chair tetap akan berada di posisinya. Konsep ini biasanya disebut dengan gamifikasi secara real-time, di mana peserta didik diharapkan termotivasi untuk memperoleh nilai yang lebih baik.

2) Microlecture Video: Pada tahap ini micro-video dibuat dengan materi mengenai tren perkembangan teknologi. Sesuai tahapan yang ada pada Gambar. 1, microvideo ini terdiri dari tiga bagian utama, yaitu pendahuluan, inti, dan kesimpulan. Bagian pendahuluan yang berdurasi sekitar 30 detik berisi pemaparan singkat mengenai perusahaan pencetus grafik Hype Cycle dan pemaparan apa yang akan disampaikan. Bagian inti memiliki durasi sekitar 12 menit, dan ditutup dengan bagian akhir yang memiliki durasi sekitar 11 detik. Tampilan micro-video yang telah dikembangkan dapat dilihat pada Gambar. 10.

Proses pembuatan micro-video ini dilakukan dengan 3 tahapan utama, yaitu merekam pengajar yang memaparkan materi, membuat video animasi mengenai materi yang akan disampaikan, dan menggabungkan kedua video tersebut. Proses perekaman video dilakukan dengan menggunakan bantuan kamera dan microphone. Sedangkan pembuatan video animasi mengenai materi dilakukan dengan menggunakan Bandicam yang dapat menangkap layar komputer secara real-time. Dengan cara ini, maka slide berupa grafik tren siklus perkembangan teknologi dapat disajikan menjadi bentuk video. Kemudian di tahap terakhir kedua video ini digabungkan dengan menggunakan Ulead Video Studio. Proses penggabungan ini dilakukan dengan cara melakukan sinkronisasi waktu (detik) antara video pemaparan pengajar dan video animasi slide.

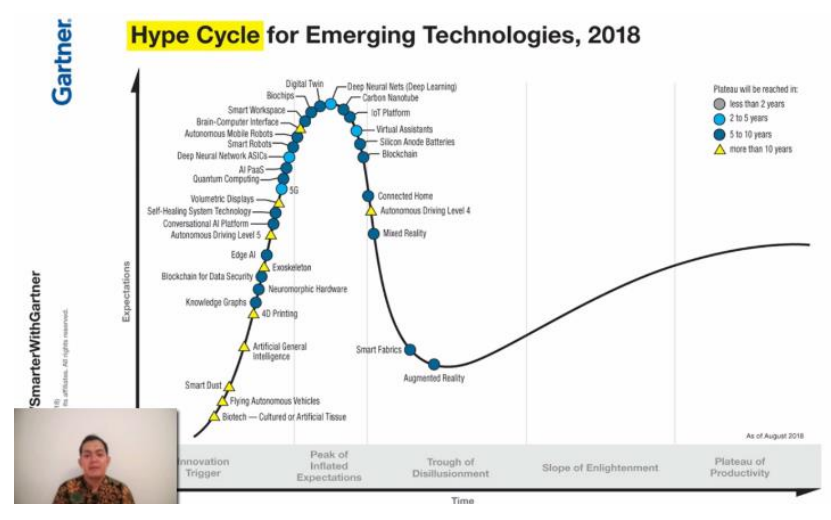

Gambar. 10 Tampilan micro-video pembelajaran

\section{Implementasi}

Pada tahap ini sistem yang telah dibuat kemudian diimplementasikan ke dalam proses pembelajaran sesuai dengan skenario pembelajajaran. Tahapan yang harus dilakukan peserta didik adalah melakukan registrasi, melaksanakan pembelajaran, dan mengikuti kuis/ujian.

1) Registrasi: Aktivitas yang dilakukan pertama kali oleh peserta didik adalah melakukan registrasi dengan cara mengakses reg-enroll booth seperti yang ditunjukan Gambar. 11. Tujuan dari proses ini adalah agar akun peserta didik di dalam sistem dapat terhubung dan terdaftar di dalam mata pelajaran (course) pada moodle dan dapat mengakses quiz chair untuk mengikuti ujian/kuis.

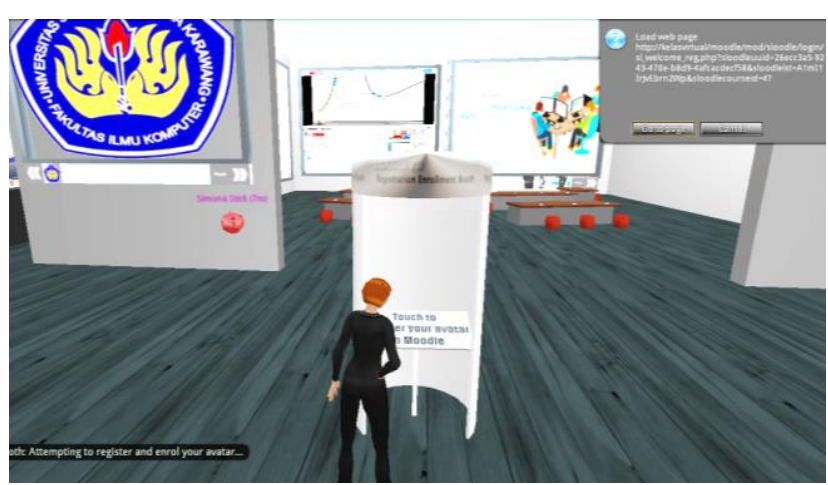

Gambar. 11 Aktivitas registrasi peserta didik

2) Pelaksanaan pembelajaran: Setelah melakukan peserta didik, peserta didik mengikuti kegiatan pembelajaran yang di dalam ruang kelas. Di dalam ruang kelas ini tediri dari dua jenis presenter, yaitu untuk menampilkan slide dan presenter sebagai web browser. Di kelas ini peserta didik dapat mengamati micro-video maupun slide yang dapat diakses melihat halaman yang diinginkan. Aktivitasi ini ditunjukan pada Gambar. 12. 


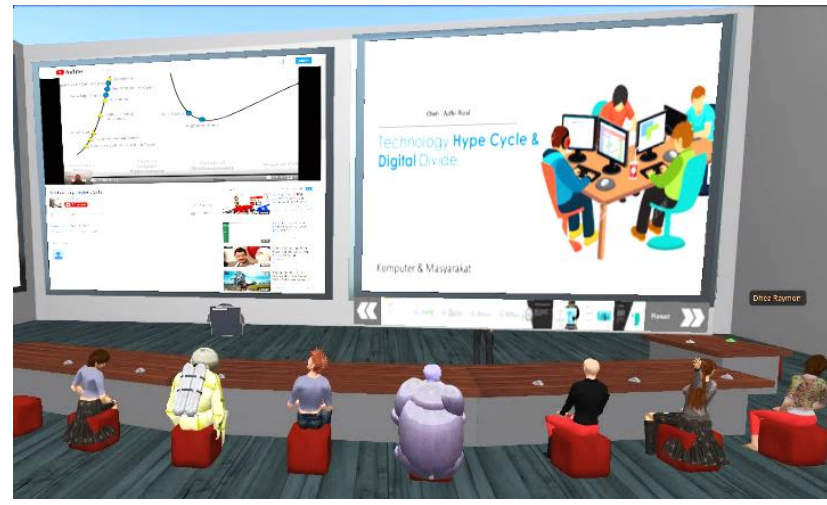

Gambar. 12 Aktivitas pembelajaran di kelas

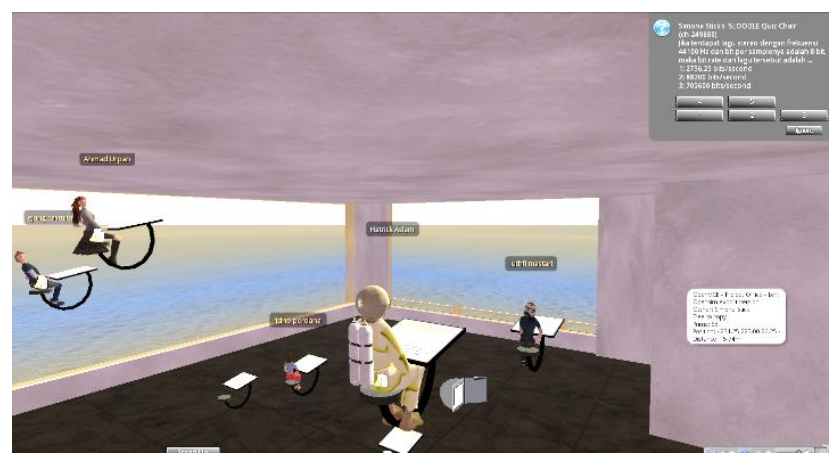

Gambar. 13 Ruang ujian menggunakan quiz chair

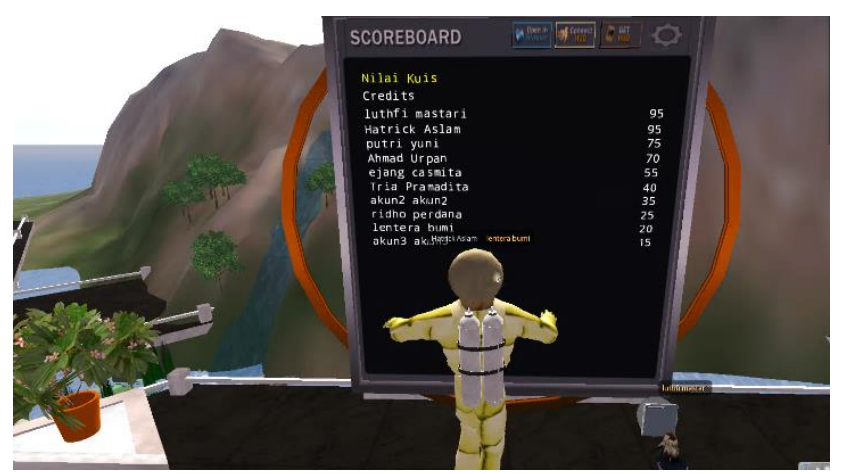

Gambar. 14 Peserta didik melihat nilai melalui scoreboard

3) Kuis/Ujian: Aktivitas ini bertujuan untuk sejauh mana pemahaman peserta didik dalam mengikuti proses pembelajaran. Di ruang ujian ini setiap peserta didik harus menempati quiz chair. Setelah menempati posisinya masing-masing, maka soal akan muncul di sudut kanan atas. Ketika peserta didik menjawab suatu soal, maka akan muncul notifikasi, baik benar maupun salah. Jika jawaban benar maka kursi yang ditempati akan bertambah tinggi, sedangkan jika jawaban salah maka kursi tidak akan bergerak dari posisinya saat ini. Hal ini dapat dilihat pada Gambar. 13 yang menunjukan bahwa jumlah peserta didik yang menjawab benar atau salah bervariasi berdasarkan ketinggiannya. Kemudian setelah peserta didik menjawab semua pertanyaan, mereka dapat melihat nilai akhirnya melalui objek Scoreboard yang ditunjukan pada Gambar. 14. Scoreboard akan menampilkan nilai yang diperoleh masing-masing peserta didik dan akan diperbarui secara otomatis setiap 60 detik. Dengan demikian, setiap peserta didik tetap dapat melihat nilainya, walaupun terdapat peserta didik yang terlambat menjawab seluruh soal.

\section{E. Evaluasi}

Proses evaluasi dilakukan terhadap hasil belajar peserta didik dan pengujian respon penggunaan sistem berdasarkan kuesioner HMSAM. Hasil belajar peserta didik diperoleh dari kelas kelas kontrol dan kelas eksperimen. Sedangkan respon pengguna hanya diperoleh dari kelas eksperimen.

1) Evaluasi Hasil Belajar: Evaluasi hasil belajar dilakukan untuk menganalisis nilai pre-test dan post-test yang diperoleh dari kelas kontrol dan eksperimen. Rentang nilai yang digunakan pada penelitian ini adalah $0-100$. Nilai rata-rata pre-test dan post-test dari masing-masing kelas dapat dilihat pada Gambar. 15.

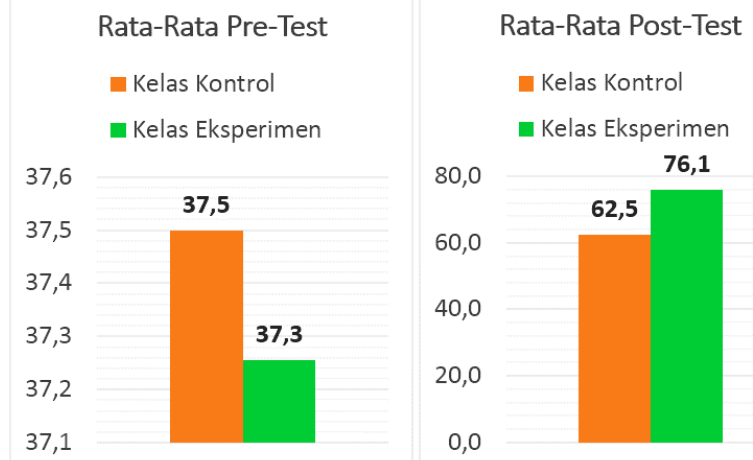

Gambar. 15 Rata-rata nilai pre-test dan post-test

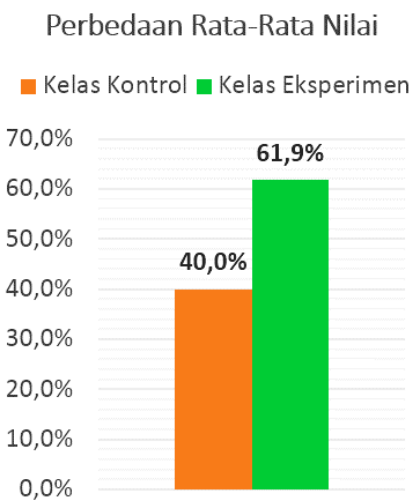

Gambar. 16 Perbedaan rata-rata nilai (gain) pre-test dan post-test kelas kontrol dan eksperimen

Gambar. 15 menunjukan nilai rata-rata pre-test kelas kontrol dan kelas eksperimen masing-masing 37,5 dan 37,3 yang menunjukan bahwa kelas kontrol lebih unggul daripada kelas eksperimen. Walaupun demikian, perbedaan tersebut hanya memiliki selisih sebesar 0,2. Berbeda dengan nilai post-test, rata-rata nilai yang diperoleh kelas eksperimen lebih tinggi dibandingkan dengan kontrol 
dengan perolehan masing-masing sebesar 62,5 dan 76,1 dengan selisih 14.

Berdasarkan data yang diperoleh maka Gain atau perbedaan rata-rata nilai pre-test dan post-test dari kedua kelompok kelas dapat dilihat pada Gambar. 16. Gain untuk kelas kontrol bernilai 40\%, sedangkan kelas eksperimen memperoleh Gain sebesar 61,9\%. Hal ini menunjukan bahwa kelas eksperimen memiliki peningkatan nilai dari pre-test ke post-test yang lebih tinggi dengan selisih sebesar $21,9 \%$.

Untuk menginvestigasi apakah integrasi konsep microlecture meggunakan 3D-VLE berpengaruh signifikan atau tidak terhadap hasil belajar, maka tahap berikutnya dilakukan uji hipotestis. Pengujian dilakukan untuk menguji hipotesis menggunakan uji-t 2 sampel independen. Hipotesis pada penelitian adalah sebagai berikut, $\mathrm{H}_{0}$ : tidak terdapat perbedaan yang signifikan antara hasil belajar kelas kontrol dan kelas eksperimen $\mathrm{H}_{1}$ : terdapat perbedaan yang signifikan antara hasil belajar kelas kontrol dan kelas eksperimen. Jika nilai signifikansi lebih besar dari 0,05, maka $\mathrm{H}_{0}$ diterima dan $\mathrm{H}_{1}$ ditolak, dan berlaku sebaliknya.

Gambar. 17 menunjukan hasil uji-t dengan perolehan nilai Sig. (2-tailed) sebesar 0,041 (lebih kecil dari 0,05). Dengan demikian $\mathrm{H}_{0}$ ditolak dan $\mathrm{H}_{1}$ diterima, sehingga dapat disimpulkan bahwa penerapan integrasi konsep memiliki pengaruh yang signifikan terhadap hasil belajar peserta didik.

\begin{tabular}{|c|c|c|c|c|}
\hline \multicolumn{5}{|c|}{ Independent Samples Test } \\
\hline & & & \multicolumn{2}{|c|}{ Hasil_Belajar } \\
\hline & & & $\begin{array}{c}\text { Equal } \\
\text { variances } \\
\text { assumed }\end{array}$ & $\begin{array}{c}\text { Equal } \\
\text { variances } \\
\text { not } \\
\text { assumed }\end{array}$ \\
\hline \multirow{2}{*}{$\begin{array}{l}\text { Levene's Test } \\
\text { for Equality of } \\
\text { Variances }\end{array}$} & \multicolumn{2}{|l|}{$\mathrm{F}$} & 6,110 & \\
\hline & \multicolumn{2}{|l|}{ Sig. } & 019 & \\
\hline \multirow{7}{*}{$\begin{array}{l}\text { t-test for } \\
\text { Equality of } \\
\text { Means }\end{array}$} & \multicolumn{2}{|l|}{$\mathrm{t}$} & $-2,133$ & $-2,172$ \\
\hline & \multicolumn{2}{|l|}{ df } & 31 & 24,398 \\
\hline & \multicolumn{3}{|l|}{ Gig. (2 tailed) } & ,040 \\
\hline & \multicolumn{2}{|c|}{ Mean Difforenoe } & 2,0725 & 2,0735 \\
\hline & \multicolumn{2}{|c|}{ Std. Error Difference } & ,97213 & ,95487 \\
\hline & \multirow{2}{*}{$\begin{array}{l}95 \% \\
\text { Confidence } \\
\text { Interval of the } \\
\text { Difference }\end{array}$} & Lower & $-4,0562$ & $-4,0426$ \\
\hline & & Upper &,- 09086 &,- 10447 \\
\hline
\end{tabular}

Gambar. 17 Hasil uji-t 2 sampel independen

Saat tahap implementasi sistem, ketika peserta didik petama kali login ke dalam sistem, pada awalnya mereka bingung dan tidak mengetahui apa yang harus dilakukan. Seperti yang dipaparkan dalam [9], sebagian besar dari mereka melakukan kustomisasi avatarnya masing-masing dan mengeksplorasi lingkungan virtual sehingga proses pembelajaran tidak terlaksana dengan efektif. Walaupun demikian, ketika masuk ke dalam ruang kelas dan disajikan micro-video beserta presenter yang menampung slide materi ajar, mereka mulai mengikuti proses pembelajaran dengan baik. Oleh karena itu, integrasi konsep yang diusulkan merupakan salah satu alternatif penunjang kegiatan pembelajaran yang dapat meningkatkan hasil belajar peserta didik.

2) Analisis HMSAM: Hasil penerimaan pengguna terhadap sistem yang telah dikembangkan dapat dilihat pada Gambar. 18. Dari semua variabel yang terdapat pada HMSAM, terdapat dua variabel yang memilki nilai di bawah 70, yaitu Control dan Perceived Ease of Use dengan perolehan nilai masing-masing sebesar $61,5 \%$ dan $65,6 \%$. Kedua variabel tersebut masing-masing berkaitan dengan kemudahan dalam mengendalikan avatar dan interaksi avatar dengan objek dan lingkungan virtual di sekitarnya. Hasil penerapan sistem menunjukan bahwa ketika pertama kali peserta didik masuk ke dalam lingkungan virtual, mereka merasa kesulitan atau kebingungan dan tidak tahu apa yang harus dilakukan, seperti mengubah tampilan dan mengoperasikan avatar, berinteraksi dengan objek, dan melaksanakan kegiatan pembelajaran. hal inilah yang menyebabkan rendahnya perolehan nilai dari dua variabel tersebut. Walaupun demikian, semakin lama dan sering menggunakan sistem, peserta didik mulai terbiasa dan leluasa mengendalikan mengendalikan avatarnya untuk berinteraksi dengan objek-objek yang ada pada sistem.

Meskipun terdapat dua variabel yang memiliki nilai rendah, namun secara keseluruhan rata-rata perolehan nilai berdasarkan hasil kuesioner adalah sebesar 78,61\%. Berdasarkan hasil ini, maka peserta didik setuju bahwa sistem yang dikembangkan dapat beroperasi dengan baik dan memenuhi kebutuhan mereka sebagai teknologi penunjang proses pembelajaran.

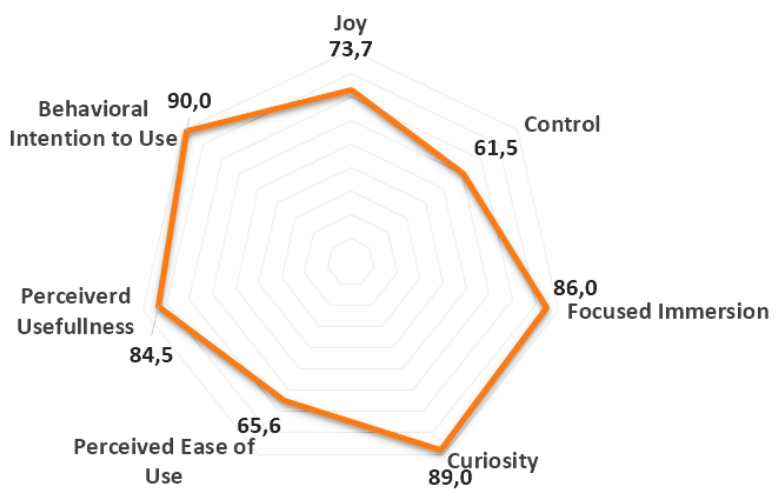

Gambar. 18 Hasil uji HMSAM (dalam \%)

Penelitian ini merupakan pengembangan dari penelitian sebelumnya, karena peserta didik mengalami penurunan hasil belajar. Hal ini disebabkan karena pada penelitian tersebut peserta didik lebih banyak melakukan eksplorasi terhadap lingkungan virtual dibandingkan dengan mengikuti proses pembelajaran. Namun dengan adanya penerapan microlecture di penelitian ini, maka peserta didik dapat lebih fokus untuk mengikuti proses pembelajaran. Berdasarkan hal ini, maka tujuan penelitian berhasil tercapai yang ditandai dengan adanya peningkatan hasil belajar serta sistem yang dapat diterima dengan baik oleh peserta didik untuk diterapkan pada proses pembelajaran. 


\section{KESIMPULAN}

Penelitian ini bertujuan untuk mengintegrasikan dan mengimplementasikan konsep microlecture ke dalam sistem pembelajaran berbasis lingkungan virtual 3 dimensi (3D-VLE). Micro-video yang dikembangkan terdiri dari tiga bagian utama, yaitu pendahuluan, bagian inti, dan bagian penutup yang masing-masing memiliki durasi sekitar 30 detik, 12 menit, dan 11 detik. Video pembelajaran ini dibuat dengan bantuan kamera, microphone, dan beberapa video editor tools. Selain mengembangkan micro-video, penelitian ini juga berhasil mengembangkan lingkungan pembelajaran virtual 3 dimensi menggunakan framework ADDIE. Lingkungan virtual yang dikembangkan memiliki objek-objek 3 dimensi layaknya di dunia nyata untuk melaksanakan kegiatan pembelajaran. Setelah lingkungan virtual selesai dikembangkan, maka micro-video dimasukan ke dalamnya dan disajikan di dalam kelas melalui suatu objek yang disebut presenter sehingga dapat dipelajari oleh peserta didik.

Berdasarkan hasil pengujian, integrasi konsep yang diusulkan memiliki pengaruh berupa peningkatan terhadap hasil belajar peserta didik dibandingkan dengan pembelajaran konvensional. Selain itu hasil uji penerimaan pengguna berdasarkan HMSAM juga menunjukan bahwa secara keseluruhan sistem yang dikembangkan dapat diterima untuk digunakan oleh peserta didik dalam melaksanakan pembelajaran.

\section{UCAPAN TERIMA KASIH}

Penelitian ini didanai dari Hibah Penelitian Dikti tahun 2019. Oleh karena itu Penulis mengucapkan terimakasih kepada Dikti dan juga pihak-pihak terkait yang telah mendukung kami dalam penyelesaian penelitian ini.

\section{REFERENSI}

[1] M. Chau, A. Wong, M. Wang, S. Lai, K. W. Chan, T. M. Li, D. Chu, I. K. Chan dan W.-k. Sung, "Using 3D virtual environments to facilitate students in constructivist learning ," Decision Support Systems 56 (2013), pp. 115-121, 2013.

[2] D. Livingstone dan J. Kemp, " Integrating Web-Based and 3D Learning Environments: Second Life Meets Moodle," CEPIS UPGRADE: European Journal for the Informatics Professional, pp. 8-14, 2008.

[3] B. Mennecke, E. M. Roche, D. A. Bray, Konsynski, Benn, Lester, John, Rowe, Michael, Townsend dan A. M., "Second Life and Other Virtual Worlds: A Roadmap for Research," dalam 28th International Conference on Information Systems (ICIS), 2007, 2007.

[4] J. Carey, "Expressive communication and social conventions in virtual worlds," ACM SIGMIS Database: the DATABASE for Advances in Information Systems, pp. 81-85, 4 November 2007.

[5] S. E. August, M. Hammers, D. B. Murphy, A. Neyer, P. Gueye dan R. Q. Thames, "Virtual Engineering Sciences Learning Lab: Giving STEM Education a Second Life," IEEE Transactions on Learning Technologies, pp. 18-30, 2016.

[6] O. Ak dan B. Kutlu, "Comparing 2D and 3D game-based learning environments in terms of learning gains and student perceptions," British Journal of Educational Technology, vol. 48, no. 1, pp. 129144, 2015.
[7] N. Aldoobie, "ADDIE Model," American International Journal of Contemporary Research, 2015.

[8] O. De Troyer, F. Kleinermann dan A. Ewais, "Enhancing Virtual Reality Learning Environments with Adaptivity: Lessons Learned," dalam HCI in Work and Learning, Life and Leisure, Berlin, 2010

[9] A. Rizal, R. I. Adam dan Susilawati, "Sistem Kelas Virtual dan Pengelolaan Pembelajaran berbasis 3-Dimensional Virtual World," Jurnal Edukasi dan Penelitian Informatika, vol. 4, no. 2, pp. 132140, 2018.

[10] Y. Hoan Cho dan K. Y. T. Lim, "Effectiveness of collaborative learning with 3D virtual worlds," British Journal of Educational Technology, vol. 48, no. 1, pp. 202-211, 2015.

[11] C. Wen dan J. Zhang, "Design of a Microlecture Mobile Learning System Based on Smartphone and Web Platforms," IEEE TRANSACTIONS ON EDUCATION, pp. 203-207, 2015

[12] A. Rizal, R. Ibnu Adam dan Susilawati, "Pengembangan Laboratorium Virtual Fisika Osilasi," Jurnal Online Informatika, pp. 55-60, 2018.

[13] X. Li, "The Strategies of College English Teachers' Professional Development in the Network Era," Canadian Social Science, pp. 221-224, 2015

[14] D. Wu dan X. Chen, "The Study of Mobile Teaching System Based on Micro-Lecture: JAVA Flipped Classroom for Example," International Journal of Multimedia and Ubiquitous Engineering, pp. 191-198, 2015.

[15] X. Chen, W. Wang, J. Luo, Z. Fang dan G. Cen, "Responsive mobile micro-lecture online learning platform under MOOC model," dalam The 10th International Conference on Computer Science \& Education (ICCSE 2015), Cambridge, 2015.

[16] J. Koumi, "Potent Pedagogic Roles for Video," Cogent Education, 2015.

[17] T. L. Roberts, "Proposing the Hedonic-Motivation System Adoption Model (HMSAM) to Increase Understanding of Adoption of Mhedonically Motivated Systems," Journal of the Association for Information Systems, vol. 14, no. 11, pp. 617-671, 2013.

[18] Y. Peng, "Application of Micro-lecture in Computer Teaching," dalam IOP Conference Series: Earth and Environmental Science, 2019.

[19] K. Yu, "Design and Application of Micro-video Course Recording in "General City Planning" Course," International Journal of Emerging Technologies in Learning, vol. 11, no. 5, pp. 16-21, 2016.

[20] X. Zhang dan J. Xu, "Integration of Micro Lectures into the Blended Learning Discourse in Tertiary Education," Asian Association of Open Universities Journal, pp. 13-28, 2015.

[21] C. Peterson, "Bringing ADDIE to Life: Instructional Design at Its Best," Journal of Educational Multimedia and Hypermedia, pp. 227-241, 2003.

[22] J. Tong, "Application of microlectures in teaching visual basic programming," World Transactions on Engineering and Technology Education, pp. 554-558, 2014.

[23] X. Liu dan L. Wang, "The Analysis on Systematic Development of College Microlecture," Higher Education Studies, 2013.

[24] OpenSimulator, "About Us: OpenSimulator," 24 January 2017. [Online]. Available: http://opensimulator.org/.

[25] Eduserv, "Online Learning in Virtual Environments with SLOODLE," University of the West of Scotland, 2009.

[26] R. Martenstyaro dan Y. Rosmansyah, "A framework for designing survey training based on 3D Virtual Learning Environment using SLOODLE," dalam Information Technology Systems and Innovation (ICITSI), 2015 International Conference, Bali, 2015. 